\title{
Resilience of Women Victims of Domestic Violence in South Minahasa District of North Sulawesi Province
}

\author{
Deflita Lumi $^{1}$, Novita Sianturi ${ }^{2}$, Priscila Rampengan ${ }^{3}$ \\ ${ }^{1,2,3}$ Christian Education of IAKN Manado, Bougenville Street Tateli 1 Mandolang, Minahasa, North \\ Sulawesi
}

\{deflitalumi@iakn-manado.ac.id¹,novitapsianturi@gmail.com², rampenganpriscila@gmail.com³

\begin{abstract}
Domestic violence is a treatment to someone in this case is female, that caused the emergence of both physical and psychic suffering that perfomed by the couple who live in the bonds of marriage. Women who experience the violence from men who are their couple in marriage, can experience health problems, stress and even lead to depression. Nevertheless, many of the women in the domestic were trying to cover the problems from the people around them including their family. They strive as hard as possible to adapt with the pressures experienced. The ability to endure in this difficult situation is called resiliency. Where resiliency is the quality of a person in terms of ability to deal with suffering. Resiliency focuses the victim using their strength rather than seeing what has happened to them. Based on the explanation, this study aims to see how resilience in women who are experiencing domestic violence in South Minahasa regency. This research is expected to provide benefits in the form of increasing references to the institutions that handle domestic violence cases. This research will use qualitative research methods, where research is conducted on natural conditions and researchers as a key instrument. The sampling of data sources is done with purposive and snowball.
\end{abstract}

Keywords: Resilience, Women Victims of Domestic Violence, South Minahasa District Of North Sulawesi Province.

\section{Introduction}

Domestic violence is a form of treatment against a person in this case women, which resulted in the emergence of both physical and psychological suffering that is done by the spouse in matrimony. Violence experienced by women in the household could even lead to the neglect of household including threat to commit acts, coercion and deprivation of freedom / liberty unlawfully within the domestic sphere. Based on data from Komnas Perempuan in Indonesia in 2018, there were 348446 cases of violence against women, and 335062 were cases of violence on wife that lead to divorce. Of 335062 cases, 416 cases occurred in the province of North Sulawesi, $40 \%$ of the 416 cases occurred in South Minahasa (Minsel), Based on these data, it was clear that domestic violence require greater attention.

There are many different types of cases of domestic violence or KDRT that occurred in the province of North Sulawesi. In Manado, a wife being victims of abuse initials NM husband (ZS) battered. The persecution triggered by financial problems, Other domestic violence cases are husband (FM) beating on his wife (AM) 'till his wife was lying on the side of the road a short distance from the victim's home, Domestic violence does not only happen in Manado, but from the data obtained, domestic violence also occurs in North Minahasa Regency 
(Minut), where an official with the initials TS violence on his wife PL due to jealousy, In the area Kotamobagu, it was reported that in 2017, there were 11 cases of violence against women in the household, in 2018 there were 10 cases of domestic violence, and in early 2019 had occurred one case of domestic violence, While in South Minahasa region, there are some examples of cases like the beating husband (N) against his wife (S) out of jealousy, Another case is a husband (D) to strangle his wife (M) just because the wife wake up her husband to help keep their children aged 7 months, There are also cases of beatings husband (F) of his wife, which resulted in the face swelling and pain in the head to the left, Here are some cases of domestic violence occurred ins North Sulawesi province.

In Asia, especially Southeast Asian community with a strong oriental culture, maintaining harmony in the family is one thing that is very valuable. This is what makes the women who experience domestic violence cases still choose to live with her husband. Religious teachings also influenced wife's decision to stay afloat maintain the integrity of households, especially in the teachings of the Christian religion, which forbids divorce, because of what God has joined together by the bond of marriage should not be separated by man.

The violence that occurred in the household, has an impact on the relationship between husband and wife first impact on the wives who have experienced violence. Women who had experienced violence from a male partner in a marriage, may experience health problems, stress and even lead to depression, However, many of the women who experience domestic violence trying to cover up the problems of close people, including their family. They tried wherever possible to adapt to the pressures experienced. Because for women, especially in Indonesia, tells the violence experienced in other people is considered as a form of behavior embarrassing family even large families on both sides. The ability to survive in difficult situations is called resilience. Where the quality of a person's resilience in terms of ability to cope with suffering,

There are several aspects of resilience, that emotion regulation is the ability to remain calm under stressful conditions; impulse control such as the ability to control desire, encouragement, joy, and the pressure arising from within; optimistic is the belief that he has the ability to overcome adversity that happened and believes that there is a good future; Causal analysis refers to an individual's ability to accurately identify the causes of the problems faced; empathy is the individual's ability to read the signs of emotional and psychological others; self efficacy of conviction that he has the ability to solve problems and; achieve success with regard to how a person is able to take a positive meaning of life after the misfortune that befell him,

Based on the research that has been done, it was found that victims of domestic violence who are trying hard to be more resilient to appreciate its power, wants to comfort others and build a purpose in life. Resilience focuses victim uses his powers over to see what had happened to him. The victims who have resilience will see their power in a way to know their response to violence. With the awareness of their power, can help victims of domestic violence to deal with his condition by implementing a strategy to face the problem,

A victim is considered able to adapt and have resistance to stressful conditions in this case of domestic violence, if the victim is able to carry out effective efforts to address the problems faced. But if the victim was not able to find and implement effective efforts, then the question will be very difficult to get out of the pressures due to domestic violence.

Based on the presentation, researchers need to look to see how the resilience of women who have experienced domestic violence in South Minahasa regency. It is driven to the fact high number of cases of domestic violence in Indonesia, especially North Sulawesi. Researchers hope the results of this study can add references and referrals to agencies that 
handle cases of domestic violence. This study will use qualitative research method, where the studies were conducted in the state of nature and researchers as a key instrument. The sampling of the data source is purposive and snowball.

Based on the results of research conducted in five women victims of domestic violence in South Minahasa Wilaya, obtained good results through interviews and observations showed how the resilience they did during their marriage. In general, they do not have the desire to divorce so that there are already survived until the age of marriage of 45 years. In addition they have no desire to divorce, the five subjects also keeps problems experienced from a large family. Even if there is a family who tried to inquire about the violence experienced, then they would defend their husbands, and some even say that the injuries suffered as a result of their own negligence (fall, inadvertently splashed boiling water, scratched by a cat).

In general, they perform some way to deal with violence experienced. As for how - how that is done is, they succumb to say anything when experiencing treated rudely from her husband either verbally or physically, other than that they chose to dodge a way out of the house for some time, until the situation meredah and then returned home to try to talk slowly with her husband. In addition, they submit totally to the Lord in prayer, because they have confidence that in time, the husband will change towards the better their religion also teaches that marriage can only be separated by death.

\section{Result and Discussion}

The issue of violence are rampant today, a variety of reasons ranging from the driver of the economic, social and cultural. However, factors that stand out from all the causes of such violence are economic factors. Address the problem of domestic violence in particular violence against women, the Bible connects household relationships in a Christian family, which is love. Love in the family was a preventive measure in order for a household to live in peace sehjahtera and loving Christ. Since the beginning of creation, marriage is not a human idea. Marriage is God's idea. In the first chapter of Genesis:

God said, "Let us make man in our image, in our likeness, and let them rule over the fish of the sea and the birds of the air and over the cattle and over all the earth." So God created man in his own image, in the image God created him, male and female he created them. God blessed them, and God said to them. "Be fruitful and multiply, fill the earth and taklukanlah it, and have dominion over the fish of the sea and the birds of the air and over every living thing that moves upon the earth" (Gen. 1: 26-28).

God created humans to be like himself. Being "in the image and likeness" means that man becomes a reflection of the nature of God. Mankind which includes men and women are created to think as God thinks, speaks as God speaks, act as God acts, motivated as God motivated. Impulses of the human mind, dreams and desires, hopes and love between men and women was deliberately designed to reflect the way God's dream, this what God would want and expect, and how God loves.

Two people involved in marriage are two different people, they have different likes and dislikes, and preferences will differences of opinion over how mattersthings that should be done, different attitudes, different backgrounds, different personalities, different mindset, and different talents and abilities. Violence is not a lifestyle and a way to solve the problem. Housekeeping is a place of learning in building relationships and interpersonal relationships. The better the quality of relations between husband and wife, continued to show the quality of 
the family relationship. Each family member needs to develop an attitude of obedience and love becomes a way to relate between husband and wife, for they are called to love one another, just as Christ loved the fellow human beings. Marriage is a picture of Christ with the church. Therefore, domestic violence is contrary to God's plan for every family.

\section{References}

[1] Anderson, Enhancing Resilience in Survivors of Family Violence, New York: Springer Publishing Company, 2010

[2] Connor \& Davidson, Development of The New Resillience Scale. Journal of Depression and Anxiety. Vol 18.

[3] Hines, Darell L, Christian Marriage, Conflicts and Solutions, Jakarta: BPK Gunung Mulia, 2018 Lawson, Incidence, Explanations and Treatment of Partner Violence. Journal of Counseling and Development, Vol 81, 2003

[4] Reivich \& Shatte, The Resillience Factor: 7 Essential Skills for Overcoming Life's Inevitable Obstacles, New York: Broadway Books, 2002.

[5] Note Violence against Women, Komnas Perempuan, Jakarta, March, 2018

[6] Manado.tribunnews.com, August, 2018

[7] Manado.tribunnews.com, February 4th, 2019

[8] TRIBUNMANADO.CO.ID, February 13th, 2019

[9] Manado.tribunnews.com, March 18, 2019

[10] https://daerah.sindonews.com, 4 November 2018

[11] https://beritamanado.com, 7 November 2018

[12] https://daerah.sindonews.com, 22 November 2018 